\title{
ESTIMATION OF THE INNOVATIVE PROJECTS INVESTMENT POTENTIAL AT THE MACHINE BUILDERS (EVIDENCE FROM LLC "TURBOMASH")
}

\author{
Sergii ILLIASHENKO', Oleg OLEFIRENKO², \\ Sumy State University, Ukraine
}

\begin{abstract}
The object of the article is to investigate methodic approach to modeling and formalized estimation of the innovative projects investment potential at the machine builders at different stages of innovative cycle. Methodology. The suggested methodic approach foresees integration: adaptive model of the detailed multifactorial operative analysis concerning innovative project efficiency, features priority of which is determined by relative dispersion formal method, allowing to estimate project efficiency probability; trinomial model of the costs formation at the innovative projects stages, observed in view of pessimistic, average and optimistic approaches. Scientific results. The practically oriented methodic of the innovative projects deep analysis is developed generally and at separate stages in its realization. It allows to estimate probability of their realization efficiency considering alternative actions development. The suggested methodic approach use gives ability to evaluate investment attractiveness of the innovative project introduced both by machine building and other economic branches enterprises, considering specific and structure of costs through expected financial result calculation. The calculated factors with its help allow to evaluate quantitively reasonability to introduce concrete innovative projects, to control innovative activity of the enterprises, particularly at the stage of decision making in their realization. And this in its turn, allows to decrease risk to make inadequate managerial decisions, to increase efficiency of the investmentinnovative activity management. Practical importance. Approbation of the suggested methodic approach at the machine builder LLC "Turbomash" during analysis of the innovative project investment attractiveness confirms its practical importance and adequacy. Authors' investigations can be introduced into practice to control enterprises investment-innovative activity.
\end{abstract}

Key words: innovations, investment attractiveness of the project, machine building, industry, life cycle.

JEL Classification: O31, O32, M31

\section{Introduction}

Machine builder efficient activity providing in conditions of the increasing competition both on the side of native and foreign producers causes modern actions and means to grow profitability as the given economy subject factor for further development. Introduction of the innovative projects is one of the important directions to use such modern actions and foresees to achieve several tasks, including: to keep constant buyer; to develop new sales markets; to bring new good to the market; to optimize enterprises costs. The given tasks realization is oriented to grow enterprise competitiveness at the market and to improve its financial results factors. However, one should pay attention to the fact that amid financial resources limitation at the native financial market there is a question of the innovative projects investment reasonability.
Involvement of costs to finance some projects has problems. For example, own capital strengthening leads to great costs for stock issues (if it is corporation), in case of their partial realization enterprise can have losses. In addition to it, as a rule, emitting paper holdings, issuer is oriented on one large investor, who is able to buy all stock, however the proper investor's aims provide not maximization of the company profits and some payments from them, but control over enterprise, that complicates to make some independent managerial decisions. Mobilization of credit resources for industrial enterprises also has some problems, because such enterprises scales and their activity complicate searching of such bank, which can fully finance enterprises needs, owing to the little resource capitalization and National Bank of Ukraine normative limitations. Involving of costs from other

\footnotetext{
Corresponding author

${ }^{1}$ Marketing and Management of Innovative Activities Department, Sumy State University;

Marketing Department, University of Economics and Humanities, Poland.

E-mail: Illiashenko.s@gmail.com

${ }^{2}$ Marketing and Management of Innovative Activities Department, Sumy State University.

E-mail: oolefirenko@turbomash.sumy.ua
} 
sources, for instance, bounded debts, are less used by Ukrainian enterprises through problem of the native fund market insufficient development.

Problems of the analysis concerning innovatively active industrial enterprises activity, and also introduced by them innovative projects, are revealed in works of the leading foreign and native scientists, among which there are (Rubenstein, Chakrabarti, OKeefe, Souder, Young, 1976), (Hall, Lerner, 2009), (Page, 1993), (Kotler, 2004), (Roizman, Grishyna, 1998), (Illyashenko, 2010), (Marketing, 2010), (Bezrukova, Dobrosotsky, 2010), (Krylov, Vlasova, Zhuravkova, 2003), (Innovative management, 2010), etc.

Analysis of publications and economy practice testifies that problems of the reasonability to introduce innovations in production are studied full enough. At the same time, in terms of dynamic shifts both in world and native economy, followed with disbalances of the financial flows move concerning enterprise ability to provide personal competitiveness through innovatively active activity financing is essentially decreased and the problem of innovative projects investment attractiveness adequate estimation is not totally solved.

Object of the article is to formalize innovative project investment attractiveness estimation model at the machine builder at different stages of its life cycle.

\section{Methodic grounds of the multifactorial innovative process analysis}

Main task of the industrial enterprise, while choosing the innovative development strategy, is the process to make such innovative decisions, which will assist to minimize costs and risks on the way to achieve the set targets. The practice testifies that most innovative projects are accepted to be introduced without coordination with marketing service, although innovative marketing allows to evaluate reasonability of such innovations development and introduction.

In the context of innovative project investment attractiveness research it is necessary to investigate the methodic approach which allows quantitively to estimate impact of the costs investment in the innovative projects on the proper enterprise financial results getting. This estimation will give additional information about reasonability to introduce suggested innovative projects and assists to make effective managerial decision. Besides, as a result of the received positive effect economy subject will be able to uphold the status of the innovatively active enterprise that is competitive advantage at the industrial market.

Thus, let's observe author's approach concerning model to estimate investment attractiveness of the concrete innovative project. Essence of the given model consists in calculation of the financial result after proper project realization by enterprise, based on the combination: adaptive model of the innovative project efficiency operative analysis, features priority of which is determined with relative dispersion formal method, providing estimation of the project efficiency probability; trinomial model of the costs formation at the innovative project stages, observed in view of pessimistic, average and optimistic approaches. Practical approbation of the model is proposed to carry out while analyzing the innovative project LLC "Turbomash" (Sumy, Ukraine), which foresees the production of the new good - granulating mill.

Considering the mentioned aspects, the efficient factor to estimate investment attractiveness of the concrete enterprise innovative project, is suggested to calculate:

Fin $\operatorname{Re} z_{t}=I N C \cdot p_{P R t}-Y N$ Vitr $r_{t}$,

where Fin $\operatorname{Re} z_{t}$ - financial result after introduction of the innovative project by the enterprise in $t$-month of its life cycle; INC - income from introduction of the innovative project by the enterprise; $p_{P R t}$ - probability of the innovative project efficiency in $t$-month of its life cycle; $Y N V_{\text {itr }_{+}}$- explicit and implicit costs of the enterprise from innovative project introduction in t-month of its life cycle.

The constituents of the ratio (1) are complicated functional dependencies on some variables. Thus, one suggests to observe methodic to form every constituent of formula in details (1).

The first stage is to calculate enterprise innovative project introduction income (table 1).

Table 1

Incoming and calculated data to define innovative project introduction income by LLC "Turbomash", UAH

\begin{tabular}{|c|l|c|c|}
\hline \multicolumn{1}{|c|}{ Factor } & \multicolumn{1}{|c|}{} & $\begin{array}{c}\text { Before innovative } \\
\text { project introduction }\end{array}$ & $\begin{array}{c}\text { After innovative project } \\
\text { introduction }\end{array}$ \\
\hline 1 & $\begin{array}{l}\text { Clear profit (clear profit (earnings) from production realization (goods, works, } \\
\text { service) and other operational incomes) }\end{array}$ & 18015546,00 & 22845146,00 \\
\hline 2 & Variable expenses, including: & 13115317,49 & 15885961,10 \\
\hline 2.1 & costs of sales (goods, works, service) within variable costs & 13115317,49 & 15885961,10 \\
\hline 3 & Gross margin (1-2) & 4900228,51 & 6959184,90 \\
\hline 4 & Constant costs, including: & 3424825,45 & 3974825,45 \\
\hline 4.1 & costs of sales (goods, works, service) within constant costs & 1297119,31 & 1347119,31 \\
\hline 4.2 & administrative costs & 989844,77 & 1289844,77 \\
\hline 4.3 & selling outlays & 463907,67 & 583907,67 \\
\hline 4.4 & other operational costs & 673953,71 & 753953,71 \\
\hline 5 & Financial result after operational activity (3-4) & 1475403,06 & 2984359,45 \\
\hline
\end{tabular}


If one analyzes main income and cost-intensive financial flows, which enterprise has before innovative project realization and which it expects to get in future from sales amounts, it is reasonably to notice their absolute growing by all article data.

The second stage of the model is to determine efficiency probability to introduce innovative project by the company, and its conduct requires implementing several steps.

First of all, it is necessary to define factors of the enterprise operational analysis, i.e. features of efficiency to introduce project before and after innovations realization by the company: operational activity income (E1); gross margin (E2); break even point (E3); financial strength supply (E4); financial strength supply coefficient (E5); power of the operational leverage impact (E6).

Having determined the factors of operational analysis, one has to estimate quantitively priority of the efficiency features to introduce innovative project by the company, using the formal method of the relative dispersion, which foresees the formula:

$$
\begin{aligned}
& w_{i}=\frac{\delta_{i}}{\sum_{i=1}^{6} \delta_{i}}, \\
& \delta_{i}=\frac{\max E_{i}-\min E_{i}}{\max E_{i}}=1-\frac{\min E_{i}}{\max E_{i}},
\end{aligned}
$$

where $w_{i}$ - weighing coefficient of $i$-factor to estimate innovative project introduction efficiency by the company; $\max E_{i}$ - maximal value of $i$-factor to estimate innovative project introduction efficiency by the company; $\min E_{i}-$ minimal value of $i$-factor to estimate innovative project introduction efficiency by the company.

After mathematic transformations formula (2) will be:

$$
w_{i}=\frac{\delta_{i}}{\sum_{i=1}^{6} \delta_{i}}=\frac{\frac{\max E_{i}-\min E_{i}}{\max E_{i}}}{\sum_{i=1}^{6} \frac{\max E_{i}-\min E_{i}}{\max E_{i}}}=\left(1-\frac{\min E_{i}}{\max E_{i}}\right) / \sum_{i=1}^{6}\left(1-\frac{\min E_{i}}{\max E_{i}}\right) \text {. }
$$

Considering practical calculations by the formula (3), there is necessity to make the following steps: to choose maximal value in view of every factor, to choose minimal value in view of every factor, to calculate ratio of swing to the maximal value, to calculate efficient factor - weighing coefficients of factors to estimate innovative project introduction efficiency by machine building company (table 2 )

According to results, showed in the table 2, weighing coefficients are distinguished in the following way: operational activity income - 0,2992, financial strength supply - 0,2641; financial strength supply coefficient and та power of the operational leverage impact - per 0,1763; gross margin - 0,0634; break even point $-0,0207$. Such distinguish of the weighing coefficients is explained by their priority in the impact on final efficient factor formation - profit. That's why, the most significant impact on the final effect keeps operational activity profit and financial strength supply.

Determination of the introduced innovative project efficiency probability provides transition from absolute to the binary values of innovative projects introduction efficiency factors by the company. If the factor growing positively influences the investment project efficiency, indicator is identified as stimulator and is given the binary characteristic "1". If the factor growing makes backward effect, it is identified as disincentive and is given binary characteristic "0" (in this case it is break even point). Due to the formalization results of this stage the following conclusions are received. The probability of the innovative project realization efficiency during the realization year is increased from 0,0207 to 0,9793 , however it is necessary to mention that such growing has uneven character at the proper project stages. Probability of the realization efficiency is low during some time - during first five months its value doesn't exceed 0,1, since 6-th till 9-th month probability value grows from 0,11 to 0,34 . Practically, during three last months, project realization probability is increased in three times (table 3 ).

Table 2

Average calculations to determine efficiency probability before and after introduction of the innovative project by the enterprise

\begin{tabular}{|c|c|c|c|c|c|c|c|c|}
\hline $\begin{array}{c}\text { Project } \\
\text { characteristic }\end{array}$ & Weighs & $\begin{array}{c}\text { Maximal } \\
\text { value }\end{array}$ & $\begin{array}{c}\text { Minimal } \\
\text { value }\end{array}$ & $\begin{array}{c}(\max -\min ) / \\
\max \end{array}$ & $\begin{array}{c}\text { Standard } \\
\text { defection }\end{array}$ & Normative value & \multicolumn{2}{c|}{$\begin{array}{c}\text { Binary factors (before and } \\
\text { after project introduction) }\end{array}$} \\
\hline A & 1 & 2 & 3 & 4 & 5 & 6 & 7 & 8 \\
\hline E1 & 0,2992 & 2984359,45 & 1475403,06 & 0,5056 & 1066993,29 & 1917366,15 & 0 & 1 \\
\hline E2 & 0,0634 & 0,30 & 0,27 & 0,1071 & 0,02 & 0,28 & 0 & 1 \\
\hline E3 & 0,0207 & 13048290,73 & 12591270,05 & 0,0350 & 323162,42 & $12914432,47^{*}$ & 1 & 0 \\
\hline E4 & 0,2641 & 9796855,27 & 5424275,95 & 0,4463 & 3091880,49 & 6704974,78 & 0 & 1 \\
\hline E5 & 0,1763 & 0,43 & 0,30 & 0,2979 & 0,09 & 0,34 & 0 & 1 \\
\hline E6 & 0,1763 & 3,32 & 2,33 & 0,2979 & 0,70 & $3,03^{*}$ & 0 & 1 \\
\hline \multicolumn{7}{|c|}{ Efficiency probability of the innovative project implementation } \\
\hline
\end{tabular}

Notice: * factor-disincentive; E1 - operational activity income, thousand UAH; E2 - gross margin, \%; E3 - break even point, thousand UAH; E4 - financial strength supply, thousand UAH; E5 - financial strength supply coefficient, \%; E6 - power of the operational leverage impact, unit

Table 3

Dynamics of the innovative project introduction efficiency probability factor change during the year

\begin{tabular}{|c|c|c|c|c|c|c|c|c|c|c|c|c|}
\hline Month & 1 & 2 & 3 & 4 & 5 & 6 & 7 & 8 & 9 & 10 & 11 & 12 \\
\hline$w_{i}$ & 0,02 & 0,03 & 0,04 & 0,06 & 0,08 & 0,11 & 0,17 & 0,24 & 0,34 & 0,49 & 0,69 & 0,97 \\
\hline
\end{tabular}




\section{Scenario analysis of the innovative project expenses}

Next step to create conceptual model is to calculate explicit and implicit costs of the enterprise from innovative project introduction (table 4).

Trinomial model of the costs formation from innovative project introduction depending on its life cycle stage foresees identification of three scenario concerning costs increase depending on life cycle stage:

1 month:

- pessimistic approach:

YNVitr ${ }_{1}=\max _{i=1 \div 3}\left\{Y N\right.$ Vitr $\left._{1 i}\right\}$,

where

$$
\begin{aligned}
& \text { YNVitr }_{11}={ }_{Y N \text { Vitr }} \cdot \eta_{11}={ }_{Y N \text { Vitr }} \cdot{ }={ }_{Y N \text { Vitr }} \cdot \exp \left(\sigma \cdot \sqrt{2 \cdot \frac{T}{N}}\right) \text {, } \\
& \text { YNVitr }_{12}=\text { YNVitr } \cdot \eta_{12}=\text { YNVitr } \cdot d=\text { YNVitr } \cdot \exp \left(-\sigma \cdot \sqrt{2 \cdot \frac{T}{N}}\right) \text {, } \\
& \text { YNVitr }_{13}=\text { YNVitr } \cdot \eta_{13}=\text { YNVitr } \cdot m=\text { YNVitr; } \\
& \text { - average (nominal) approach: } \\
& \text { YNVitr }_{1}=\frac{\sum_{i=1}^{3} \text { YNVitr }_{1 i}}{3} \text {; } \\
& \text { - optimistic approach: } \\
& \text { YNVitr } \min _{i=1 \div 3}\left\{Y_{\text {N Vitr }}\right\} \text {; }
\end{aligned}
$$

Analogically to the approach described above, costs from innovative project introduction for 2-12 stages of its life cycle.

At the final stage of the model creation, let's calculate financial result after innovative project introduction by the enterprise foe each forecast. Presenting graphically financial results after innovative project introduction by LLC "Turbomash" at different stages of its life cycle (fig. 1), we point out that profitability can be seen since $7^{\text {th }}$ month for optimistic approach; therefore total sum of the investment attractiveness factor in the project is $1233673 \mathrm{UAH}$. Lower, but profitable results (63833 UAH) allow to get average approach, by which income increase is started from $8^{\text {th }}$ stage of the innovation life cycle. The worse situation, peculiar for pessimistic approach, by which positive money flows are expected only since $10^{\text {th }}$ month; therefore generally observed innovative project is unprofitable in sum $1344911 \mathrm{UAH}$.

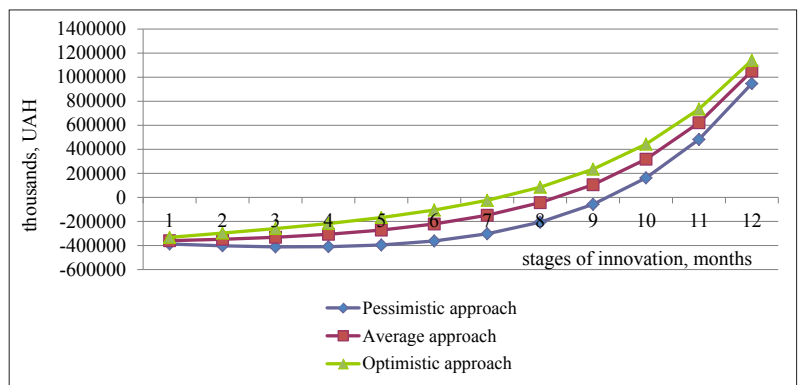

Fig. 1. Dynamics of the innovative project investment attractiveness depending on its life cycle stage

The average (real) forecast provides profit, however in terms of the financial instability while making decision concerning the proper project realization one has to take a ply to pessimistic scenario. That's why in order to realize the given innovative project as line extension and new market segment gain, risk-management of the enterprise must take measures concerning leveling of the studied project risks.

\section{Conclusions}

The practically oriented methodic of the innovative projects deep analysis is developed generally and at separate stages in its realization. It allows to estimate probability of their realization efficiency considering alternative actions development. The suggested methodic approach use gives ability to evaluate investment attractiveness of the innovative project introduced both by machine building and other economic branches enterprises, considering specific and structure of costs through expected financial result calculation. The calculated factors with its help allow to evaluate quantitively reasonability to introduce concrete innovative projects, to control innovative activity of the enterprises, particularly at the stage of decision making in their realization. And this in its turn, allows to decrease risk to make inadequate managerial decisions, to increase efficiency of the investment-innovative activity management. Approbation of the suggested methodic approach at the machine builder LLC “Turbomash" during analysis of the innovative project investment attractiveness confirms its practical importance and adequacy. Authors' investigations can be introduced into practice to control enterprises investment-innovative activity. The received quantitative factors may be used as objective source to make managerial decision concerning innovative project realization reasonability.

Table 4

Explicit and implicit costs of LLC "Turbomash" from innovative project introduction

\begin{tabular}{|c|l|c|}
\hline Expenses type & \multicolumn{1}{|c|}{ Expenses constituents } & Sum of expenses, UAH \\
\hline \multirow{5}{*}{ Explicit expenses (EICPI) } & L - license cost to use innovative project technologies & 25200,00 \\
\cline { 2 - 3 } & IE - expenses for project technology introduction & 217160,24 \\
\cline { 2 - 3 } & ST - personnel training acts & 9356,00 \\
\cline { 2 - 3 } & DE - additional equipment & 8150,00 \\
\hline \multirow{5}{*}{ Implicit expenses (IICPI) } & WE - employees' wages, involved to introduce project technologies for a time & 34740,87 \\
\cline { 2 - 3 } & AP - additional payments (bonus) for employees for extra-normative work & 84211,76 \\
\cline { 2 - 3 } & $\mathrm{CM}$ - cost of the adaptations, conducted by developer or renewing & 5734,00 \\
\cline { 2 - 3 } & PV - non-production expenses & 5100,00 \\
\hline \multicolumn{2}{|c|}{ Total } & 389652,87 \\
\hline
\end{tabular}




\section{References}

Bezrukova, T.L., Dobrosotsky, T.L. (2010). Formation of the investment attractiveness in the innovative project control process. Innovative economics, 9(9): 27-31.

Illyashenko, S.M. (2010). Strategic management of the innovative activity at the enterprise, based on the innovations marketing. Urgent problems of economics. 12: 111-119.

Innovative management: Conceptions, multilevel strategies and mechanisms of the innovative development: teaching guide (2010) / edited by V.M. Anshyn, A.A. Dagayev. - 3d issue, modified and added - M. : Delo: 584 p. Hall, B.H., Lerner, J. (2009). The Financing of R\&D and Innovation. NBER Working Papers \# 15325. - National Bureau of Economic Research, Inc. -55 p.

Kotler, F. (2004). Marketing-management: Express-course : Tramsl. From eng. edited by Yu.N. Kapturevsky. SPb.: Peter, - 496 p.

Krylov, E.I., Vlasova, V.M., Zhuravkova, I.V. (2003). Analysis of the investment and innovative activity efficiency at the enterprise: teaching guide. - M.: Finances and statistics. 608 p.

Marketing. Management. Innovations: Monograph (2010) / Edited by Dr of Economics, S.M. Illyashenko. - Sumy: LLC "Publishing house "Papirus",- 624 p.

Page, A.L. (1993). Assessing new product development practices and performance: Establishing crucial norms. Journal of Product Innovation Management. 10. - P. 273-287.

Roizman, I.I., Grishyna, I.V. (1998). Existing and perspective investment attractiveness of the large branches in native industry. Investments in Russia. 1:37-39.

Rubenstein, A.H., Chakrabarti, A.K., OKeefe, R.D., Souder, W.E., Young, H.C. (1976). Factors Influencing Successat the Project Level. Research Management. 19(5): 15-19.

\section{Сергей ИЛЬЯШЕНКО, ОЛег ОЛЕФИРЕНКО}

\section{ОЦЕНКА ИНВЕСТИЦИОННОЙ ПРИВЛЕКАТЕЛЬНОСТИ ИННОВАЦИОННЫХ ПРОЕКТОВ} МАШИНОСТРОИТЕЛЬНЫХ ПРЕДПРИЯТИЙ (НА ПРИМЕРЕ ООО «ТУРБОМАШ»)

Аннотация. Целью статьи является разработка методического подхода к моделированию и формализованной оценке инвестиционной привлекательности инновационных проектов машиностроительных предприятий на разных стадиях инновационного цикла. Методика. Предложенный методический подход предусматривает комбинирование: адитивной модели детализированного многофакторного операционного анализа эффективности инновационного проекта, приоритетность характеристик которого определяется формальным методом относительного разброса, что позволяет оценить вероятность эффективности проекта; триномиальной модели формирования расходов на этапах инновационного проекта, рассмотренных в разрезе пессимистического, среднестатистического и оптимистичного подходов. Научные результаты. Разработана практически ориентированная методика углубленного анализа инновационных проектов - как в целом, так и на отдельных этапах их реализации, которая позволяет оценить вероятность эффективности их реализации с учетом альтернативных сценариев развития событий. Использование предложенного методического подхода дает возможность оценить инвестиционную привлекательность инновационного проекта внедряемого предприятиями машиностроения и других отраслей экономики, учитывая специфику и структуру расходов каждого из них, путем расчета ожидаемого финансового результата. Рассчитанные с его помощью показатели позволяют количественно оценить целесообразность внедрения конкретных инновационных проектов, целенаправленно управлять инновационной деятельностью предприятий, в частности, на стадии принятия решений об их реализации. А это, в свою очередь, позволяет снизить риск принятия неадекватных управленческих решений, повысить эффективность управления инвестиционно-инновационной деятельностью. Практическое значение. Апробация предложенного методического подхода на машиностроительном предприятии ООО "Турбомаш" в ходе анализа инвестиционной привлекательности инновационного проекта подтвердила его практическую значимость и адекватность. Авторские разработки могут быть непосредственно внедрены в практику управления инвестиционно-инновационной деятельности предприятий. 